Katarzyna Wrońska*

ORCID: 0000-0001-6617-4415

Krakow, Poland

\title{
The Praise of Self-Instruction in the 21st Century - against a Background of Selected Concepts of Self-Education in Poland during the Partitions and Interwar Period
}

\section{Pochwała samouctwa w XXI wieku - na tle historycznych propozycji samokształceniowych w Polsce czasów zaborów i międzywojnia}

\begin{abstract}
In the text, the author considers the present sense and meaning of self-instruction - in connection to the issue of being alone - against a background of selected historical concepts of self-education in Poland. Considering education and its role in learning to think, the author assumes that being alone as a mode of human existence is a philosophical starting point. Therefore, self-instruction presents itself as an adequate example, illustrating the possibility of experiencing solitude and learning to be alone as a way of being a person. In the times of the partitions, self-instruction was a very popular postulate among Polish intellectuals involved in activities promoting civil and patriotic attitudes, in a country subjected to denationalising
\end{abstract}

* Dr. hab. Katarzyna Wrońska, Associate Professor, Faculty of Philosophy, Institute of Education, Jagiellonian University in Kraków, email: katarzyna.wronska@uj.edu.pl. 
politics. In the interwar period, the concepts of self-instruction were still developing, due to defects in the created official school system at the time. The author focuses on one such concept, created by Władysław M. Kozłowski. Kozłowski himself assessed his work for the education of compatriots as fulfilling a civil duty and acting for a free and democratic Poland. Today, recalling the concept of self-instruction allows us to see it as a necessary humanizing complement to school education in Poland, balancing between the extremes of encyclopaedism and instrumentalism. It can be used to bring out a few arguments for education not being reduced to professionalisation and which promotes the human condition as vita activa.

Keywords: self-instruction; solitude; aloneness; thinking; self-education; education.

Abstrakt: W tekście autorka proponuje rozważyć dzisiejszy sens i znaczenie samouctwa - w powiązaniu z zagadnieniem osobności - na tle wybranych historycznych koncepcji samokształceniowych w Polsce. Osobność jako sposób istnienia człowieka jest dla autorki filozoficznym punktem wyjścia w rozważaniach nad edukacją i jej rolą w uczeniu myślenia wymagającego bycia ze sobą samym (u siebie). W związku z czym samouctwo prezentuje się jako adekwatny przykład ilustrujący możliwość doświadczania i uczenia się osobności jako sposobu bycia. W czasach zaborów samouctwo było hasłem popularnym postulowanym w gronie polskich intelektualistów zaangażowanych $\mathrm{w}$ działalność krzewiącą postawy obywatelskie i patriotyczne w kraju poddanym zaborczej wynaradawiającej polityce. W międzywojniu w dalszym ciągu koncepcje samouctwa były rozwijane z powodu wad w tworzonym oficjalnym systemie szkolnictwa. Autorka skupia uwagę na jednej z koncepcji, tworzonej przez Władysława M. Kozłowskiego. Sam Kozłowski oceniał swoją pracę na rzecz kształcenia się rodaków jako spełnianie obowiązku obywatelskiego i działanie na rzecz wolnej i demokratycznej Polski, która wymaga od swoich obywateli rozumu i samodzielności. Przywoływanie dziś koncepcji samouctwa pozwala widzieć ją jako potrzebne humanizujące dopełnienie szkoły w Polsce, balansującej między skrajnościami encyklopedyzmu i instrumentalizmu. Można z owej koncepcji wydobyć wiązkę argumentów na rzecz wykształcenia niesprowadzalnego do uzawodowienia a sprzyjającego kondycji ludzkiej jako vita activa.

Slowa kluczowe: samouctwo; samotność; osobność; myślenie; wykształcenie samego siebie; wychowanie i kształcenie. 


\section{Introduction}

Self-instruction is perceived mainly as a remedy for an absence of education. In my presentation, I will try to measure its value, particularly under present Polish conditions. Today's crisis in education is a state in which, more than by its shortages, we are threatened by its use of political tools and instrumentalisation. What are the symptoms of this crisis? Firstly, we can observe it in the form of preserving encyclopaedism; and secondly, in the form of reductionism and the instrumentalisation of school education, by both the authorities and its recipients. We inherited encyclopaedism from the days of the classical high school (Gymnasium), mainly in the Prussian model (Alves, 2019). It was common in Prussia and in Polish territories under Prussian rule (according to the formula: gaining knowledge depends on memorising facts, discipline in the form of drilling, the system of the school hierarchy, and dependence on the authority of the teacher: professor and the headmaster).

During the Polish People's Republic, encyclopaedism (used in the communist countries) was the norm in general secondary schools. And today, the school education is again becoming a weapon in the hands of authority, which aims to achieve its goals through the education of the youth. On the other hand, the entities of education increasingly think of it as a means of climbing career levels - and here education reveals its second extremum, reductionism and instrumentalism, without reducing the burden of encyclopaedism. Can such a state of education be conducive to thinking? I assume this makes it difficult. It shifts thinking exercise to a later stage of life reserving the possible establishment with scholastic thinking for school ${ }^{1}$.

Thinking is not a common practice at all, and education in a crisis may neglect the need to think. Certainly it is adjusted and stimulates the subject's activity (including cognitive), but it is not necessarily based on thinking. But is it conducive to the development and acquisition of mental abilities (having an open, critical mind) and personality skills (attitudes of independence, responsibility)? One may have some doubts. What, then, is conducive to thinking?

${ }^{1}$ See: Hugo Kołłątaj (ed. 1953) writing about 'scholastic thinking' as a problem of Polish education at the end of the 18th century in: Stan oświecenia $w$ Polsce $w$ latach panowania Augusta III (1750-1764) [The state of enlightenment in Poland in the last years of August III (1750-1764)]. This is a censored work, published in its entirety only in the second half of the 20th century. 
In my text, I will argue that what fosters and creates excellent conditions for thinking is solitude, a state of being at home with oneself. It is not a popular thesis. Furthermore, at present, everything seems to contradict this thesis. Our presence in culture is largely carried out through modern information technology, such as smartphones and tablets. Today, they are our window to the world. Through these devices we connect with others; and not only with our close ones. These devices give us the feeling that we are in constant potential - communication with people all over the world, and can keep us up to date with everything that is happening worldwide. It is common to see people staring at their smartphone screens, reading from them, exchanging messages or talking with someone; this creates the picture of our cities and our everyday life, in the public space and beyond. But is this a pure way of meeting and conversation - in a modern version? And are we then available to ourselves? I doubt it. Are we not neglecting ourselves? Perhaps looking at smartphones shows not our openness to the world and others; but rather, our loneliness, fear, and an avoidance of reading inside ourselves, which inhibits contemplation and reflection. It can also simply describe our lack of preparation for a meeting with our own thoughts. This is how the Canadian writer Patrick deWitt (2019) approached this matter in an interview, describing how smartphones take away our solitude. I treat him as an ally of this thesis, as regards the human need for solitude which is threatened today, underestimated and distorted into the form of loneliness (isolation, rejection). And if we are so addicted to smartphones and rarely have a chance to experience our aloneness, then perhaps the task of education should be to learn how to deal with and manage without such devices, and to be able to practise being alone with ourselves.

For me, aloneness as a mode of human existence is a philosophical starting point in considering human education, and the role of solitude in teaching thinking, which requires being at home with oneself. However, I do not want to treat solitude as an end in itself. The key is to capture its positive side, as a method that enables people who are busy, anxious and uprooted to experience being alone, being with themselves; as a method to stop and increase the ability to experience thinking, and reflection about themselves, others and the world. Thinking, in turn, I would like to view as an end in itself, as the value of a person; as one's name, which is at the same level as one's freedom and openness to dialogue and meeting with others.

To this end, I propose to refresh the concept of self-instruction, treating it as a remedy for today's education crisis, in the culture of smartphones. I consider it as a voice that encourages learning to be with oneself, and learning to 
experience aloneness as a meeting with oneself and with the thinking mind. Also, as a necessary humanising complement to school in Poland, balancing between the extremes of encyclopaedism and instrumentalism. I have researched historical pedagogical texts from 100 years ago (the times of shortages of public education in Poland because of the partitions), and draw on arguments from today's perspective, for renewing the sense of education and its use. I recall mainly one figure - Władysław Kozłowski - who lived in the years 1858-1935, and thus experienced captivity, including deportation to Siberia, then the rebuilding of statehood and a system of public education. Kozłowski himself assessed his work for the self-education of his countrymen as fulfilling a civil duty and acting for a free and democratic Poland, which requires reason and independence from its citizens.

I assume that as a result of the analysis of self-instruction, it will be possible to demonstrate the value of solitude in a person's life; the need to learn and experience aloneness as a way of being alone (with oneself) and as a school of thought. In summary, I would like to present a few arguments for education being not limited to professional training, but conducive to the human condition as vita activa - extracted from the concept of self-instruction.

\section{Aloneness as experiencing oneself and as a school of thought}

Being alone (with oneself), being separately as a way of human existence (being a person, being a personal being), is my philosophical starting point in the consideration of education and its role in teaching thought, on the basis that thinking requires the subject to be at home with themselves. This sense of being a person - separately - is manifested in various forms. Starting from the very beginning, a small child still has no educated ability to recognise themselves as a separate self, speaks about themselves in the third person, sees themselves a manner indistinguishable from their surroundings, and is afraid of separation from their mother. On the other hand, autonomy is regarded as the goal of human development. Between these extremes exists a whole spectrum of intermediate forms through which one passes, when progressing from infancy and dependence to autonomy. This time is filled by education. In this space, one should as a learner attend to the dimension of being with oneself.

Genetically, an encounter is what precedes thinking triggered by a single subject; the experience of the proximity of a person who is ready to ac- 
cept the trust of a child. Józef Tischner - a Polish philosopher of dialogue gave his views on meeting and thinking, in relation to the pedagogical scene. $\mathrm{He}$ argued that the beginning of thinking lies in meeting and conversation. 'Nothing gives us food for thought, like the other' - he said (Tischner, 2008, p. 130). For him, dialogue was the beginning of all experience of the world, including the experience of God. In every form of dialogue, a human being is invited to think; including ethical thinking (to be truthful towards others, not to lie to them, to be faithful to them, to be a confidant of someone's hopes) and religious thinking (including touching the limits of thought). In the next step, and thus a step forward, it is necessary to constantly balance dependence relations (dependence on the educator / teacher / peer) with self-education experience. This new experience is the opportunity offered by the problem of self-solution, which is set by the learner, or the teacher whom the learner trusts (in addition to the assigned tasks). As we remember, in the case of John Stuart Mill, the dependent (all-encompassing) relationship with his father first required separation from his pedagogical relationship with him, so that his education would take the form of an independent educational work, including experiencing being alone without the feeling of deprivation (Wrońska, 2012, pp. 108-110).

At this point I would like to recall a few remarks by the phenomenologist Roman Ingarden, about a person with a reference to aloneness. In the view of the author of Ksiazieczka o człowieku [A Little Book about a Man], the value of a man as a person lies in the fact that he is crystallised, integrated, or on the way to his crystallisation and integration. One's centre is a living, personal 'I', a conscious entity. This 'I' as a person has a character, is free (aware of their own freedom), and is thus a centre of action, capable of grasping the initiative; while on the other hand, they must be relatively isolated from the environment. A human is a person at least in potentia. In the course of one's life, one can develop one's personal potential (potential as a person). Among the personal values that are worth nurturing and improving in one's life, in his book Wyktady z etyki [Lectures on Ethics], Ingarden distinguished awareness, freedom, strength of character, intelligence, happiness, versatility, depth, independence, internal criticism, and individuality. These values are, according to him, the basic equipment of a person, but when neglected, they may reveal their lack or opposite: that is, character weakness, intellectual dullness, lack of understanding, spiritual poverty, shallowness of feelings and thoughts, dependence, dogmatism, and a quality of being anonymous. In addition to the above, he also distinguished the very value of a person - this concept of merging, crystallising, integrity. It means 
that even though a person is subjected to time-bound, historical changes, they still maintain a durable, essential core; this is the basis and the source of both quality development processes and the individual manner in which the interaction takes place between a person and the world. It is only on the basis of this psychophysical integration that Ingarden provides the dimension of the person's dignity. This special dignity is given to the person by their moral deeds (Ingarden, 1989). 'I am the strength - he claims - that wants to be free. One can only last and be free if one voluntarily gives oneself up to produce goodness, truth and beauty. Only then one exists' (Ingarden, 1987, p. 68).

It is obvious that the moral dimension of human existence requires openness to dialogue and involvement in the affairs of others. But space and time for solitude should also be defined and outlined if one is to feel at home with oneself in that specific time and space, involved and capable of involvement, and able to leave oneself to meet with others. Being alone at a mental level, as a creature capable of reflection, finds its fulfillment at the level of action in relation to another human being and in the community. Hannah Arendt devotes great attention to this issue in The Human Condition, by considering and reinterpreting two faces of the human being: the vita activa - the activity of a person, being an actor of events and initiator of actions; and vita contemplativa - human reflexivity and distancing. It is also valuable to recall her distinction between private and public spheres, where in the first she places secretiveness, intimacy; while the public contains everything that is important and should be contributed to the forum, spoken in front of others and implemented for others (as a public matter) (Arendt, 1998). For Arendt, aloneness is not just a matter of intimacy and privacy.

In her work The Life of the Mind, Arendt makes a distinction between intellect and reason (mind), with an emphasis that the ability to think is assigned to reason. This is extremely important in connection with education. The intellect is considered to be the mental activity that is apparently practised during the years spent at school. We use the term 'intellectual education', but in the meaning of the process guided by the teacher. On the other hand, there is the case of the mind. She begins her reflection on thinking by quoting Cato's ancient thought: 'never is a man more active than when he does nothing, never is he less alone than when he is by himself' (Arendt, 1978, p. 8). Following this thought, Arendt concludes that today - regardless of the range of modern 'deaths' (such as of God, philosophy, metaphysics) 'our ability to think is not at stake; we are what men always have been thinking beings'; and that 'men have an inclination, perhaps a need, to think beyond the limitations of knowledge, to do more with this ability than to use 
it as an instrument for knowing and doing' (ibidem, p. 21). This need, in her opinion, is the result of the relationship between the ability to think and to tell right from wrong; namely that 'weakedness may be caused by absence of thought' (ibidem, p. 13). This is the problem of the so-called banality of evil; and consequently, Arendt emphasizes that "we must be able to "demand" its exercise [the ability to think] from every sane person, no matter how erudite or ignorant, intelligent or stupid he may happen to be' (ibidem, p. 13). Thus, one must distinguish between the two faculties: reason (Vernunft) and intellect (Verstand), or between two mental activities: thinking and cognition. For Arendt, Kant's distinction between knowledge and faith - in other words, that he 'found it necessary to deny knowledge ... to make room for faith' (ibidem, p. 14) - was nothing but making room for thinking.

Why do we think? In seeking the answer, Arendt turned to the ancient Greeks and the Romans. She stayed with Socrates longer, as she found him to be a teacher of thought, called by Heidegger 'the purest of the West. This is why he wrote nothing' (ibidem, p. 174). Socrates taught thinking by describing himself as a gadfly (he stung and bit people, stimulating them to think), and a midwife (he delivered people of their thoughts); he was also called an electric ray (he paralised but triggered thinking activity). He was dangerous in what he did, because he mobilised others to think; and it is thinking that makes people disobedient, not succumbed to authority. According to Arendt, what triggered the thinking of Socrates was the love (need, desire) for beauty, justice and wisdom. One has to arouse this, because without it one is unable to think. Arendt, like Socrates, argued that evil is an absence, but went a little further, to focus mainly on the absence of thinking (thoughtlessness). It would be a mistake, however, to confuse Socratic love (eros) with other emotional states, such as passions and certainty of conviction, which tend to be more of a barrier to thinking. This can be seen, for example, at rallies by politicians, ideologues, preachers; these are gatherings of crowds of followers of a given ideology or worldview, giving pre-prepared answers to various ills and problems of everyday life and beyond. This is a different way of satisfying existential needs, a regaining of a sense of security and a liberation from uncertainty and anxiety; it is competitive to thinking. Yet there is a great demand for these ideological images of reality. Therefore, should we see thinking as a privilege reserved for a limited minority? On the contrary.

Arendt, making a distinction between the intellect knowing something and reason thinking about something, defends the thesis that 
... thinking in its noncognitive, non-specialist sense as a natural need of human life ... is not a prerogative of the few, but an ever-present faculty in everybody; by the same token, inability to think is not a failing of the many who lack brain power, but an ever-present possibility for everybody - scientists, scholars and other specialists in mental enterprises not excluded. Everybody may come to shun that intercourse with oneself. (ibidem, p. 191)

It is solitude but not loneliness, because a man has himself as company. Loneliness occurs when we are unable to 'split up into the two-in-one' and to keep ourselves company (ibidem, p. 185). This two-in-one takes the form of dialogue with each other: one is talking and listening silently, and this 'heals the solitariness of thinking' (ibidem, p. 187). It also makes it possible to see a man acting wrongly as someone inconsistent with themselves. We deal with this in every situation, in which a person wants to make an exception for themselves and not adhere to the rules (applied generally, for everyone); but he or she would like others to adhere to them, and thus such a person contradicts themselves. 'A life without thinking is quite possible; it then fails to develop its own essence - it is not merely meaningless; it is not fully alive. Unthinking men' - Arendt adds - 'are like sleepwalkers' (ibidem, p. 191).

One can also wonder if we are actually alone when we think. Maybe not at all, because when we think, we can have a conversation with humanity as Michael Oakeshott would say. Therefore, if we are in such good company, loneliness as deprivation is not threatening to us. And while being at home (with yourself), you can invite others into yourself. Guests are welcome. We can accommodate a variety of voices (not only the discursive 'voice of science', but for example the voice of poetry) - because all these utterances contribute to human activity, argues Oakeshott $(1959$, p. 9). When we are at home with ourselves, we can also transcend ourselves and be for someone else, in an understanding, accepting way; such as leaning over someone's misery, or simply wanting to be close to someone or sending someone a smile. But this is a further perspective, and Arendt herself would introduce it in the work On Will. For the culmination of the thinking process as 'the two-in-one of soundless dialogue' (Arendt, 1978, p. 181), it is the power of judging that embodies thinking in the phenomenal world. At this level, we are no longer alone (with our thinking), because we are entering a world in which, among others, we decide to issue judgments about specific things and facts, and become involved in the action. In turn, Tischner, the author of Myślenie wedtug wartości [Thinking According to Values] (2002), demanded 
the necessity of waking up to thinking, a task he reserved for teachers and mentors (Tischner, 1984).

For children, but also for fearful people, concealed from the world in their hideouts and not yet awakened to think, Tischner - and also Arendt prescribe the meeting (dialogue) with the other. 'I first talk with others', explains Arendt,

... before I talk with myself, examining whatever the joint talk may have been about, and then discover that I can conduct a dialogue not only with others but with myself as well. The common point, however, is that the dialogue of thoughts can be carried out only among friends, and its basic criterion, its supreme law, says: 'Do not contradict yourself'. (Arendt, 1978, p. 189)

In Tischner's version, we find a description of the meeting, not so much with a friend as with a confidant of hope (he or she cannot fail and must speak the truth) (Tischner, 1984, pp. 66-71). Arendt and Tischner agree here: dialogue not only fills the thinking process, but also introduces and invites us to think.

Even John Dewey, an advocate of activism and teamwork in education, stressed that the educator's task is to arouse thinking, to shape a searching and reflective attitude: 'stop and think', he says, because

... all reflection involves, at some point, stopping external observations and reactions so that an idea may mature. Meditation, withdrawal or abstraction from clamorous assailants of the senses and from demands for overt action, is as necessary at the reasoning stage, as are observation and experiment at other periods ... . Reasoning is no more akin to disputing or arguing, or to the abrupt seizing and dropping of suggestions, than digestion is to a noisy champing of the jaws. The teacher must secure opportunity for leisurely mental digestion. (Dewey, 1910, p. 210)

And although he treated thinking as an instrument for solving problems and satisfying needs, he was far from using thinking for fulfilling someone's apetite or caprice. As he wrote, freedom 'does not consist in keeping up uninterruptive and unimpeded external action' (ibidem, p. 65); its true sense is intellectual, as 'freedom of mind' (ibidem, p. 64) or freedom of observation and judgment, that serves intrinsically valuable goals.

In addition to the arguments of philosophers, it is worth recalling the reflections of Patrick deWitt, a contemporary writer who praises solitude. In one of his interviews, he talks about his decision to live without the Internet. 
In his school days he experienced major learning difficulties, despite his love of reading. He admits that his love for books was aroused in him by his father. He tells us that his father, at the age of seventeen, decided to embark on a journey after reading On the Road by Jack Kerouac; he left his home forever. For this reason (and not thanks to the school), Patrick understood that books can have an enormous impact on human life. His reading, however, did not translate into success at school. Apparently, he did not read what the syllabus and teachers required. When writing his own novel, he decided to disconnect from the Internet, which took too much of his time. As he says, without the Internet he is happier and more productive.

Smartphones - he admits - have taken away moments of solitude, which are crucial for my work. When my laptop was connected to the Internet, I checked the email or turned on something on YouTube every few minutes. It took me a lot of time to return to the thread left behind (deWitt, 2019).

After writing the book, he discovered that he did not need to go back to the Internet anymore. Thanks to this change, he has gained a lot of time. Today, he says, he does not have a television, uses the simplest phone with a fliptop, and has no Internet at home. When he needs to send an email, he goes to a cafe. He spends there an hour each day, five days a week. In the remaining time he is outside the network.

If solitude allows us to experience aloneness as a way of existence and to undergo the process of learning to think, then let us move it to the field of education. But where and how can it reside in this space? I assume that at the school level it will be difficult to obtain. To what extent, if at all, does a student have the opportunity to ask a question? Are they given the task of rethinking a particular problem or finding a way to solve it, or are they allowed to activate their imagination and find a problem to investigate themselves? Apart from getting to know and understanding what the author had in mind, do they have the chance to share their own thoughts after reading a given text? Are they given any tasks that involve preparing their own questions for the text they read, their solutions to a given problem, or their interpretation of the facts, processes and events that they have learned? The diagnosis seems to be very inauspicious (Nussbaum, 2010; Postman, 2000). Is this only a problem of our modern times, or was it a problem in the past? To answer this question I will expound upon remarks from Polish history, by recalling the figure already mentioned: Władysław Kozłowski. I will try to transfer to our field his commitment to the self-education of his compatriots, in the 
service of a free and democratic Poland. Just as they were 100 years ago, his demands are still invaluable. In a different historical context, there is still the same need for education that makes people committed and sensitive citizens, rational and independent people.

\section{Wladysław Kozłowski and his criticism and postulates regarding education - praise of self-instruction}

In the era before that of Kozłowski, Hugo Kołłątaj discussed the state of the Enlightenment in Poland in the last years of August III (1750-1764). His work described the condition of our society, in which scholastic thinking prevails, as being a contradiction of a mature form based on self-reliance and independence (Kołłątaj, 1953). Let us also recall an earlier figure, John Locke, who dealt with issues concerning the conduct of the understanding, but did not include them in his text about education. Eventually, we can find them in the second volume of his main epistemological work, An Essay concerning Human Understanding. Thus, the ability of the mind as a concern for learners was discussed in his work addressed not to children but to youth and adults (Locke, 1856). Kozłowski was a translator of the first volume of this book, and we know that he supported many points of Locke's philosophy (Kozłowski, 1921). We can observe his influence especially on Kozłowski’s concept of self-education (Wrońska, 2012, pp. 62, 101).

Kozłowski often quoted another English scholar, namely the historian Edward Gibbon, who said: "we have a twofold education - one is given to us, the other is gained by ourselves, and that is what is most valuable' (Kozłowski, 1932, p. 1). Kozłowski, like Locke, praised the use of our own reason; therefore, the task of education is to promote learning to think independently. For him, education is not teaching, but a piece of mental equipment with such skills and knowledge that will enable further self-learning, or self-education. To address the permanent limitation of access to knowledge, as well as the indoctrination present in the formal education system of the Polish partitions and during World War I, Kozłowski found a way to improve the mental condition of the society; not within formal education, but as a part of self-study activity. According to him, the task of education is to develop general, but clear and precise concepts about each of the sciences. This has a twofold purpose: (1) as a means of helping us become aware of world phenomena, so we as learners know where to go and how to keep going when the need or passion makes us learn more about any subject; 
and (2) as the material from which the whole world-view is made (ibidem, pp. 149-150).

Elementary knowledge of these sciences should be within the scope of the school's work. The state of balance between schooling and self-instruction is optimal for education. We see that an imbalance between them causes the most common disadvantage of education, which is manifested firstly in being well-read, but at the same time ignorant of the foundations that a school should have given (as in the case of a wiseacre who easily switches from topic to topic and changes his views along with everything he reads). Nowadays, especially in Europe, this is in fact not very frequent, as we care about equipping children with basic knowledge. Secondly, when the self-learning is predominantly complementary to schooling, but there is no effort to educate oneself, this leads to the case of the eternal student: an encyclopaedist. Kozłowski emphasises that education, although based on broad knowledge, should not be an encyclopaedic one - not even in the smallest degree - but a synthetic one. As he states, 'not the amount of knowledge, but the ability to link the contents to each other' is the value of education. Self-education leads to the emancipation of man. However, it requires shaping beliefs that are the result of one's own work (although school should prepare the ground for this by developing emotional, cognitive and mental foundations for independent work). If schools were to entirely replace self-education, 'the fate of such a society would be miserable', asserts Kozłowski (ibidem, 1932, p. 22).

The comprehensive education of oneself creates the individual's comprehensive worldview; it integrates feelings, will, knowledge and readiness to act. What distinguishes this worldview, according to Kozłowski, is: (1) consistency, i.e. diligent removal of internal contradictions in one's experience; (2) scientific thinking, i.e. relying on knowledge and basing one's ideas on it; (3) criticism, i.e. taking into account the boundary between knowledge and faith; and (4) freeing oneself from blindly following tradition, but instead guiding oneself with ideals, using the achievements of the great artists and thinkers from the past (ibidem, pp. 111-113). He argues that if you have leisure time, and the support of institutions facilitating knowledge and learning (for example museums, libraries, open lectures, etc.) then working on yourself may exceed the effect of formal education (Kozłowski, 1902, p. 40).

Kozłowski tried to convince everyone to undertake self-instruction, explaining to his compatriots who were reluctant to learn independently without the support of 'a good school', that self-education is not at all devoid of 
mentoring. Importantly, the learner can have more influence on choosing teachers from outside the neighbourhood's immediate environment, 'among writers of all nations and ages, making use of the existence of books' (ibidem, p. 181) - as was the case for Patrick deWitt and his father. Kozłowski asked, "why would it be more shameful to learn from Plato, Kant, Laplace, and Darwin, than from Mr. X from the Gymnasium of Saint Ann in Kraków?' (ibidem, p. 181). Self-instruction as a form of self-education is the independent use of knowledge without the intermediation of a scholar-lecturer; the learning is 'open', using every situation and opportunity to acquire new knowledge and expand what is already possessed. Moreover, it also involves - in addition to reading - the contact with another person, and an openness to everything in them that can enrich us: a word, judgment, example, etc. (ibidem, p. 41). For Kozłowski, every student is and should be an autodidact. They should 'overwork' all the school material by themselves. To count on pouring wisdom into the student's head during classes for six or more hours a day is a psychological, pedagogical and also philosophical absurdity. Nevertheless, the education of oneself should be eagerly supported by the school, and teachers should rely on the readers' independence.

Kozłowski, as a critic of contemporary schooling in Poland during the interwar period, accused it of many cardinal errors. For example, (1) overloading, under the pretext of facilitating, through an excessive number of hours; and (2) teaching content that is not actually scientific, although labelled as such. In the text Uzdrowienie szkoty średniej [Healing of the secondary school], he argues that this causes increased intolerance of different views, hatred of their followers, and a lack of one's own opinion. Among his postulates for healing education, he proposed (1) abolition of the secondary school certificate; (2) spreading education in the widest possible social strata, with the inevitable consequence of removing all obstacles to entering secondary school after passing elementary school, and later to higher education institutions of all types; (3) legislative protection of children against overloading; and (4) transferring religious classes to church congregations, and introducing ethics to schools (Kozłowski, 1927, p. 3). He separately formulated his criticism of the matriculation examination [in Polish, matura] in a poignant sketch, Precz z matura!! [Down with the Matriculation Examination!]. Here he pointed out that it was a method of punishing and intimidating Polish youth during the partitions; but after regaining independence, it still remained an obsolete and unnecessary apparatus 'to extinguish lights in the nation', by supporting bureaucracy and enabling the authorities to fill 'all posts with their pawns' (Kozłowski, 1926, pp. 12-13). 
To sum up, it can be assumed that Kozłowski treated school and self-education as two separate issues: schooling creates scholars, but self-education produces educated people. Learnedness or erudition is not equal to education. True education is distinguished by two features: (1) the synthesis of 'knowledge into the whole general view', and (2) the independent fulfilment of this synthesis,

... assimilating it with our individuality ... . The first feature creates a whole picture on the basis of fragmentary information from various fields; it produces cohesive and uniform foundations on which we base our judgments; while the second makes these judgments really ours. You can learn all your life without getting an education, and have ready opinions for all possible circumstances without being the author of these judgments. (Kozłowski, 1932, p. 21)

School works well if it forms and ennobles character, teaches and develops discipline, will and mind; accustoms one to systematic and correct thinking; trains the mind and gives out basic knowledge, thus preparing one to develop beliefs, without instilling them. The goal of self-instruction is 'to elaborate answers to issues raised by life, to create beliefs which help to direct our behaviour and conduct' (ibidem, p. 23). A book will be helpful here, which you can obtain.

\section{What and how to read? - within the ideal comprehensive education of oneself}

For this purpose, Kozłowski prepared a handbook (1932) intended to help in self-instruction. Education liberates oneself from childhood, understood as dependence; it is the enlightenment of the individual. Childishness is not a fault, but abandonment of working on oneself to escape from dependence already marks the guilt. As he states in this handbook,

The ideal of true education is to give everyone the opportunity to have their own thoughts, to have their own, not borrowed, and deeply rooted judgments about life, art and knowledge. The task of education is not to make everyone a writer; but you can say that every educated person is a writer in potency. (ibidem, p. 30)

He also quotes Fichte's words: 
What way have I come to what I know? Was I driven by the pursuit to know, zest for knowledge? Did I wade through uncertainty, doubt and contradiction? ... No, I do not recall such a state. These instructions were given to me before I even wanted them; I was answered before I asked the question. I listened because I could not avoid it. (Fichte, 2002, p. 17)

Kozłowski interprets this thought as aptly catching the moment in which a person can make a decision to choose themselves as their guide in life: that is, using their own conviction, their own judgment about things, and the pursuit of critical development of this belief.

The first impulse to write this handbook was a catalogue of works from various fields to read, along with books, both sent to him by his younger brother Kazimierz, during his exile in Siberia. Kozłowski admitted that this was very useful for him. Thinking about writing a book on what to read, he wondered if it is possible to manage someone's reading without violating the individuality of a reader, and whether it is possible to prepare a catalogue of excellent books suitable for everyone. After a long consideration, he decided to develop a book that would be a collection of general methodological guidelines, but would not prejudge 'the results to which the reading will lead'; along with a list of titles 'which have earned the unwavering right to be considered valuable and educating', while avoiding imposing views, beliefs and goals. Indeed, nothing is more contrary to the concept of education than

... imposing ready-made, not critically digested and thought-out views. This way, only the herd ... is raised, the blind tools of parties are fabricated, ready to go uncritically with the slogans of their leaders. Not free, not self-thinking and not self-determining individuals. (Kozłowski, 1932, p. 15)

He admitted that the leading idea of the first editions of his handbook was the expectation that the book would be an 'educator of generations from the years of slavery'; that it would awaken the desire for independence and the desire for progress, which are crucial for the life of the nation. In the times of an independent Poland, Kozłowski came to the conclusion that this leading idea did not have to change at all, because a 'partisan spirit and sectarianism' continued to threaten the development of the individual mind, giving either ready solutions or biased ones that 'tighten their horizons' (ibidem, p. 15). Instead of promoting an impartial search for the truth, they slacken thought and will, making people accustomed to complying with the arguments of the fighting groups and their bellwethers. Thus, self-instruction has not lost its 
importance, provided that it is allowed to promote the ideal of comprehensive education.

\section{Summary}

The above considerations allow it to be stated that it is worth postulating self-instruction as a form of education that runs parallel to the formal one and continues after its completion, within the framework of a wider project of educating ourselves. It makes sense if we want education to leave room for independent choice; if want it to maintain initiatives for seeking knowledge and reading selflessly; and not be transformed into a tool and a market product ordered by various stakeholders. Secondly, self-instruction is unavoidable if we think about learning throughout life. One must be able to escape school and school thinking, which moulds the minds of children and young people, and does not help them become independent in thinking. Finally, we can take into account self-instruction as a form of resistance to schooling, but not in its extreme form of dropping out, which creates the risk of greater losses than profits, including loneliness and isolation. Indeed, an example of such resistance is seen in Poland today.

The praise of self-instruction - as part of a reflection on aloneness and solitude, as a mode of human existence - coincides with the concept of comprehensive liberal education. Here, it creates a chord in which the humanising note of non-profit education is heard (Nussbaum, 2010). Kozłowski's indications are again valid. He was convinced that everything must be done to increase the circle of intelligent people; or, in the words of Arendt, the circle of people who think. Just like Kozłowski, although I am criticising modern schooling, I do not recommend acquiring knowledge outside of school. Rather, we should remove the excess of knowledge from schools, and introduce more opportunities to meet others and ourselves (our aloneness), through dialogue and the experience of thinking - in solitude.

\section{References}

Alves, A. (2019). The German Tradition of Self-Cultivation (Bildung) and its Historical Meaning. Educação \& Realidade, 44(2), 1-18.

Arendt, H. (1978). The Life of the Mind. The Groundbreaking Investigation on How We Think. San Diego, New York, London: A Harvest Book \& Harcourt Inc. 
Arendt, H. (1998). The Human Condition. Chicago: The University of Chicago Press. deWitt, P. (2019). Smartphones took us solitude. Interview with Natalia Szostak. $G a-$ zeta Wyborcza, 01.19. http://www.wysokieobcasy.pl/wysokie-obcasy/7,127763, 24366252,smartfony-odebraly-nam-samotnosc.html [accessed: 24/03/2019]. Dewey, J. (1910). How We Think. New York, p. 210. http://www.gutenberg.org/files/ 37423/37423-h/37423-h.htm\#CHAPTER_FIFTEEN [accessed: 05.04.2019].

Fichte, J. G. (2002). Powołanie człowieka, transl. A. Zieleńczyk. Kęty: Antyk Publishing House.

Ingarden, R. (1987). Ksiażeczka o człowieku. Kraków: Wydawnictwo Literackie. Ingarden, R. (1989). Wyktady z etyki. Warszawa: PWN.

Kołłątaj, H. (1953). Stan oświecenia w Polsce w ostatnich latach panowania Augusta III (1750-1764). Wrocław: Ossolineum.

Kozłowski, W. (1902). Z haset umystowości wspótczesnej. Kraków: Editorial Office of 'Views on the World'.

Kozłowski, W. (1921). Szkic życia Locke’a i pozostałych dzieł (pp. I-XVIII). In J. Locke. O rozumie ludzkim. Warszawa.

Kozłowski, W. (1926). Precz z matura!. Warszawa-Poznań: Authors' Edition.

Kozłowski, W. (1927). Uzdrowienie szkoły średniej. Życie Wolne, 1(4).

Kozłowski, W. (1932). Co i jak czytać? Wykształcenie samego siebie i drogi do niego. Warszawa: Gebethner and Wolff.

Locke, J. (1856). An Essay concerning Human Understanding and a Treatise on the Conduct of the Understanding. Philadelphia: Hayes \& Zell.

Nussbaum, M. (2010). Not for Profit. Why Democracy Needs the Humanities. Princeton: Princeton University Press.

Oakeshott, M. (1959). The Voice of Poetry in the Conversation of Mankind. London: Bowes \& Bowes.

Postman, N. (2000). Building a Bridge to the 18th Century: How the Past Can Improve Our Future. New York: Vintage Books.

Tischner, J. (1984). The Spirit of Solidarity. Transl. M. B. Zaleski \& B. Fiore. San Francisco: Harper \& Row, Publishers.

Tischner, J. (2002). Myślenie wedlug wartości. Kraków: Znak.

Tischner, J. (2008). Spotkanie. Wywiad A. Karoń z J. Tischnerem. Kraków: Znak.

Wrońska, K. (2012). Pedagogika klasycznego liberalizmu w dwugłosie John Locke i John Stuart Mill. Kraków: Wydawnictwo UJ. 